Article

\title{
Surface Temperature Multiscale Monitoring by Thermal Infrared Satellite and Ground Images at Campi Flegrei Volcanic Area (Italy)
}

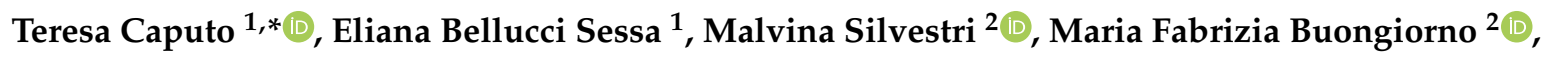 \\ Massimo Musacchio $\left.{ }^{2}{ }^{(}\right)$, Fabio Sansivero ${ }^{1}(\mathbb{C})$ and Giuseppe Vilardo ${ }^{1}$ \\ 1 Istituto Nazionale di Geofisica e Vulcanologia, Sezione di Napoli Osservatorio Vesuviano, Via Diocleziano \\ 328, 80125 Napoli, Italy; eliana.bellucci@ingv.it (E.B.S.); fabio.sansivero@ingv.it (F.S.); \\ giuseppe.vilardo@ingv.it (G.V.) \\ 2 Istituto Nazionale di Geofisica e Vulcanologia, Osservatorio Nazionale Terremoti, Via di Vigna Murata 605, \\ 00143 Roma, Italy; malvina.silvestri@ingv.it (M.S.); fabrizia.buongiorno@ingv.it (M.F.B.); \\ massimo.musacchio@ingv.it (M.M.) \\ * Correspondence: teresa.caputo@ingv.it; Tel.: +39-081-6108-215
}

Received: 6 March 2019; Accepted: 24 April 2019; Published: 28 April 2019

\begin{abstract}
Land Surface Temperature (LST) from satellite data is a key component in many aspects of environmental research. In volcanic areas, LST is used to detect ground thermal anomalies providing a supplementary tool to monitor the activity status of a particular volcano. In this work, we describe a procedure aimed at identifying spatial thermal anomalies in thermal infrared (TIR) satellite frames which are corrected for the seasonal influence by using TIR images from ground stations. The procedure was applied to the volcanic area of Campi Flegrei (Italy) using TIR ASTER and Landsat 8 satellite imagery and TIR ground images acquired from the Thermal Infrared volcanic surveillance Network (TIRNet) (INGV, Osservatorio Vesuviano). The continuous TIRNet time-series images were processed to evaluate the seasonal component which was used to correct the surface temperatures estimated by the satellite's discrete data. The results showed a good correspondence between de-seasoned time series of surface ground temperatures and satellite temperatures. The seasonal correction of satellite surface temperatures allows monitoring of the surface thermal field to be extended to all the satellite frames, covering a wide portion of Campi Flegrei volcanic area.
\end{abstract}

Keywords: land surface temperature; thermal infrared data; remote sensing multiscale monitoring; seasonality removal; Campi Flegrei

\section{Introduction}

More than 300,000 people live inside the volcanic area of Campi Flegrei, (Italy; Figure 1) that also includes part of the city of Naples (about 1 million people). Due to the high volcanic risk affecting this area, continuous seismic, geochemical and ground deformation monitoring networks, aimed at volcanic surveillance, operate in the Campi Flegrei [1-3]. In particular, the Thermal Infrared surveillance Network (TIRNet) consists of thermal infrared ground stations intended for continuous monitoring of surface temperatures of fumarole fields located inside the Solfatara crater and in the Pisciarelli area (Figure 1b) [2,4].

Volcanic surveillance based on a thermal infrared ground camera is a tool which is commonly used (e.g., in Italy, Mt. Etna [5-9] and in the USA, Hawaiian volcanoes) and the information obtained by this monitoring tool is useful for defining the local hazard level. Moreover, the use of Thermal InfraRed (TIR) satellite sensors is also a consolidated technique [10-16] for monitoring the volcanic activity at different spatial resolutions: low (e.g., Meteosat Second Generation, MSG, or the Geostationary Environmental 
Satellite, GOES), moderate (e.g., MODIS, AVHRR, Sentinel 3) and high (e.g., Advanced Spaceborne Thermal Emission and Reflection Radiometer, ASTER, and Landsat 8) [17-30]. The development of remote sensing techniques aimed at the estimation of surface temperatures of lava flows, lava lakes, and domes, as well as fumaroles of active volcanic areas, has allowed significant improvements in volcano monitoring activity [6,31-34]. Indeed, recent studies have shown thermal anomalies as an indicator of change in volcanic systems [4,35].

The availability of TIR frames acquired by both satellite Earth Observation (EO) and permanent ground stations of the Solfatara area (TIRNet), provide an opportunity to compare the two different surface temperatures retrieved. Since TIR satellite data are characterized by coarser spatial resolution with respect to TIR data from ground stations, this comparison can provide information to improve satellite data reliability.

This work reports on a procedure aimed at identifying spatial thermal anomalies over TIR satellite frames which were corrected for the seasonal influence by using surface temperature data from TIR ground stations. This procedure was tested at the Campi Flegrei volcanic area (Italy) and the results are presented.

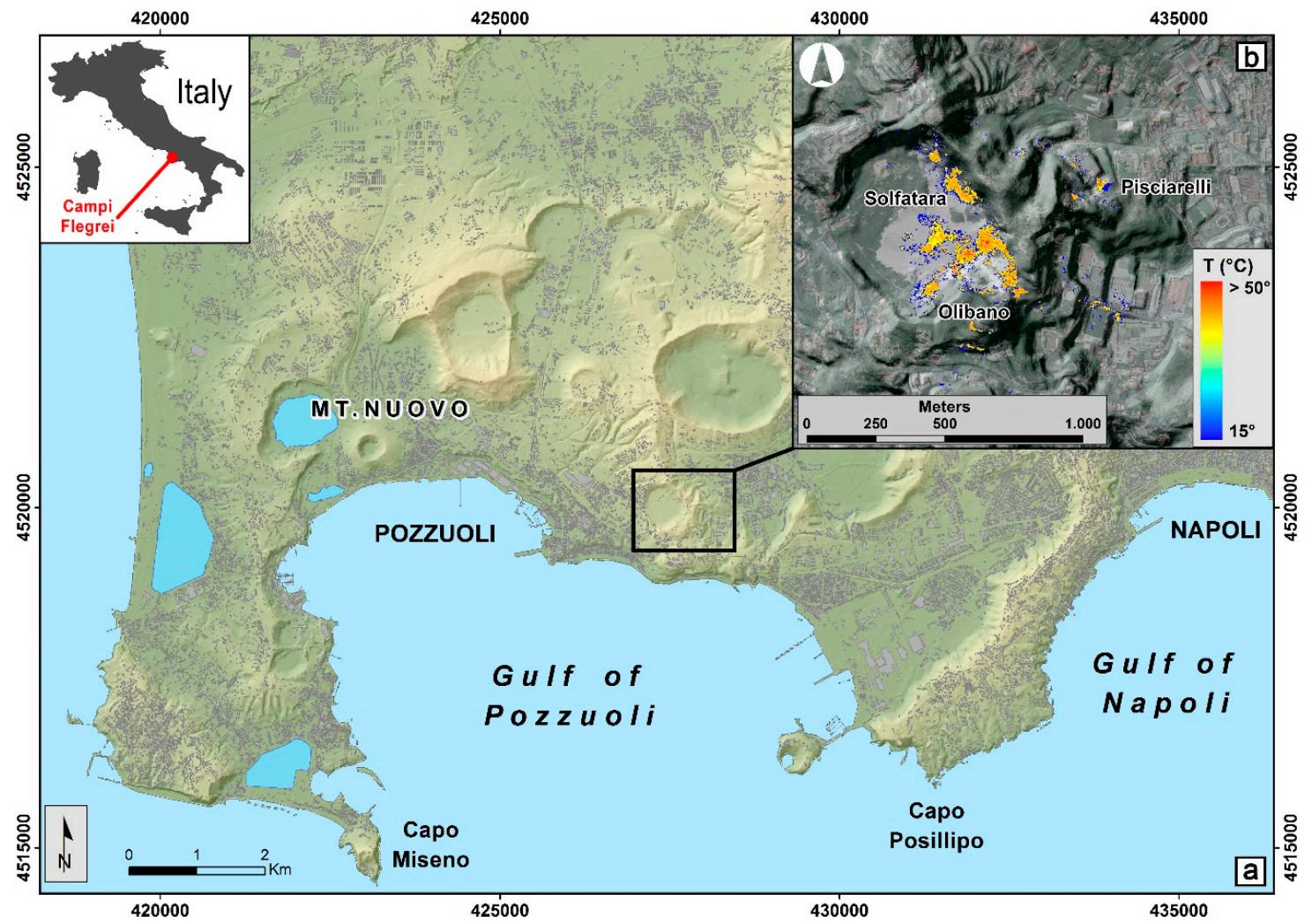

Figure 1. Painted relief map and urbanized areas (in grey) of Campi Flegrei (a) and infrared thermal image of the Solfatara crater and its surroundings (b) acquired by $3^{\circ}$ Reparto Capitanerie di Porto (Comando Generale del Corpo delle Capitanerie di Porto), using an airborne multispectral sensor Daedalus 1268 ATM Enhanced [36] on 19 December 2013, 04:00 (UTC).

\section{Brief Geological Outline of Investigated Area}

Campi Flegrei is an active volcanic field developed inside a collapsed area formed by two high energy eruptions: Campanian Ignimbrite and Neapolitan Yellow Tuff, aged 40 and 15 ka, respectively [37-42]. In the last $15 \mathrm{ka}$, after the Neapolitan Yellow Tuff eruption, almost 70 eruptions have taken place at the Campi Flegrei caldera $(\mathrm{CFc})$ and the last eruption generated the Monte Nuovo volcanic edifice (1538 AD; [43]). CFc is affected by ground vertical movements (Bradyseism) and in modern times, two significant episodes of ground uplift have occurred, with a maximum uplift of about 
$3.5 \mathrm{~m}$ in the area of Pozzuoli [44]. In the last ten years the same area has been affected by ground uplift, with vertical displacement of about $400 \mathrm{~mm}$ in the period 2008-2018 [45]. At present, the Solfatara area (Figure 1) is the highly hydrothermally active zone of Campi Flegrei, with diffuse fumaroles inside and beside the crater. Intense degassing also occurs at the Pisciarelli location (Figure 1b), at the NE of the Solfatara crater [46-49].

\section{Materials}

The data used to apply the procedure presented in this work are the surface temperatures from two different sets of data: (1) Landsat 8 and ASTER satellite TIR data; and (2) data from the TIRNet thermal camera ground network.

\subsection{Satellite Data}

\subsubsection{Landsat 8 (L8) Data}

Landsat satellites have been collecting imagery of the Earth's surface since 1972 [50], creating a huge historical archive that is unmatched. The millions of scenes held in the USGS archives provide useful support to all users worldwide. Landsat 8 (L8) is the last satellite, launched on 11 February 2013 [51]. Among the different sensors mounted on board, in this work we use the data acquired by TIRS which consists of two bands (band 10, 10.60-11.19 $\mu \mathrm{m}$ and band 11, 11.50-12.51 $\mu \mathrm{m}$ ) useful for providing accurate surface temperatures and collected at $100 \mathrm{~m}$ spatial resolution. For this work we used the TIRS channels to estimate the surface temperature in the Campi Flegrei area. By adopting L8, we have decided to use only the B10 band due to known calibration problems in the dual thermal bands of L8 [52].

The L8 satellite collects images of the entire Earth every 16 days with an 8-day offset from Landsat 7. Considering the nighttime data time series collected, excluding cloudy scenes, the analyzed L8 data are reported in Table 1.

Table 1. List of analyzed nighttime L8 data.

\begin{tabular}{ccccc}
\hline $\mathbf{2 0 1 3}$ & $\mathbf{2 0 1 4}$ & $\mathbf{2 0 1 5}$ & $\mathbf{2 0 1 6}$ & $\mathbf{2 0 1 7}$ \\
\hline & 6, 22 February & 9 February & 16 April & 3, 19 April \\
& 11 April & 13 March & 18 May & 5, 21 May \\
& 29 May & 1 June & 3 June & 6, 22 June \\
4,20 December & 30 June & 3, 19 July & 5, 21 July & 8, 24 July \\
& 16 July & 4, 20 August & 6 August & 9, 25 August \\
& 1, 17 August & 5, 21 September & 7 September & 12, 28 October \\
& 20 October & 23 October & 10, 26 November & 13 November \\
& 21 November & 8 November & 12 December & \\
7 December & 10, 26 December & &
\end{tabular}

The estimations of surface temperature were obtained by applying the procedure described in [53] and its bibliography.

\subsubsection{Advanced Spaceborne Thermal Emission and Reflection Radiometer (ASTER) Data}

The ASTER sensor launched in December 1999 is one of five instruments on the Terra satellite, part of NASA's Earth Observing System (EOS). The ASTER instrument has three sensors in the VNRI, SWIR and TIR Spectral range [54]. In this work we refer to the five bands within the thermal infrared (TIR) region (8 to $12 \mu \mathrm{m}$ ) with $90 \mathrm{~m}$ spatial resolution [55].

ASTER is the first orbital sensor that provides publicly-available high-spatial resolution data with more than two bands in the TIR region. These data enable the development of methods for extracting the small-scale compositional and temperature structure of the surface [56-58]. The list of 25 nighttime ASTER TIR scenes collected, excluding cloudy data, is reported in Table 2. 
Table 2. List of analyzed nighttime ASTER data.

\begin{tabular}{ccccc}
\hline $\mathbf{2 0 1 3}$ & $\mathbf{2 0 1 4}$ & $\mathbf{2 0 1 5}$ & $\mathbf{2 0 1 6}$ & $\mathbf{2 0 1 7}$ \\
\hline & & 17 February & & 1 March \\
12 July & 18 March & 11, 18, 20 July & 4 June & 13 May \\
3,12, 21 December & 22 June & 13 September & 6 September & 14, 21 June \\
& 26 September & 15 October & 4, 27 December & 16 July \\
& & 2, 18 December & & 2 September \\
\hline
\end{tabular}

The estimations of surface temperature were obtained by applying the procedure described in [59] and its bibliography.

\subsection{Permanent Thermal Camera Data}

The permanent Thermal Infrared Surveillance Network (TIRNet) has been developed by INGV-Osservatorio Vesuviano for the volcanic surveillance of the Neapolitan area. In the Campi Flegrei area, five stations have been installed for daily acquisition of thermal infrared data of diffuse degassing areas characterized by significant thermal anomalies. These areas are located inside and outside the Solfatara crater, in the surrounding areas of the Mt. Olibano lava dome and at Pisciarelli (SF1, SF2, OBN, PS1 and SOB stations; Figure 2).

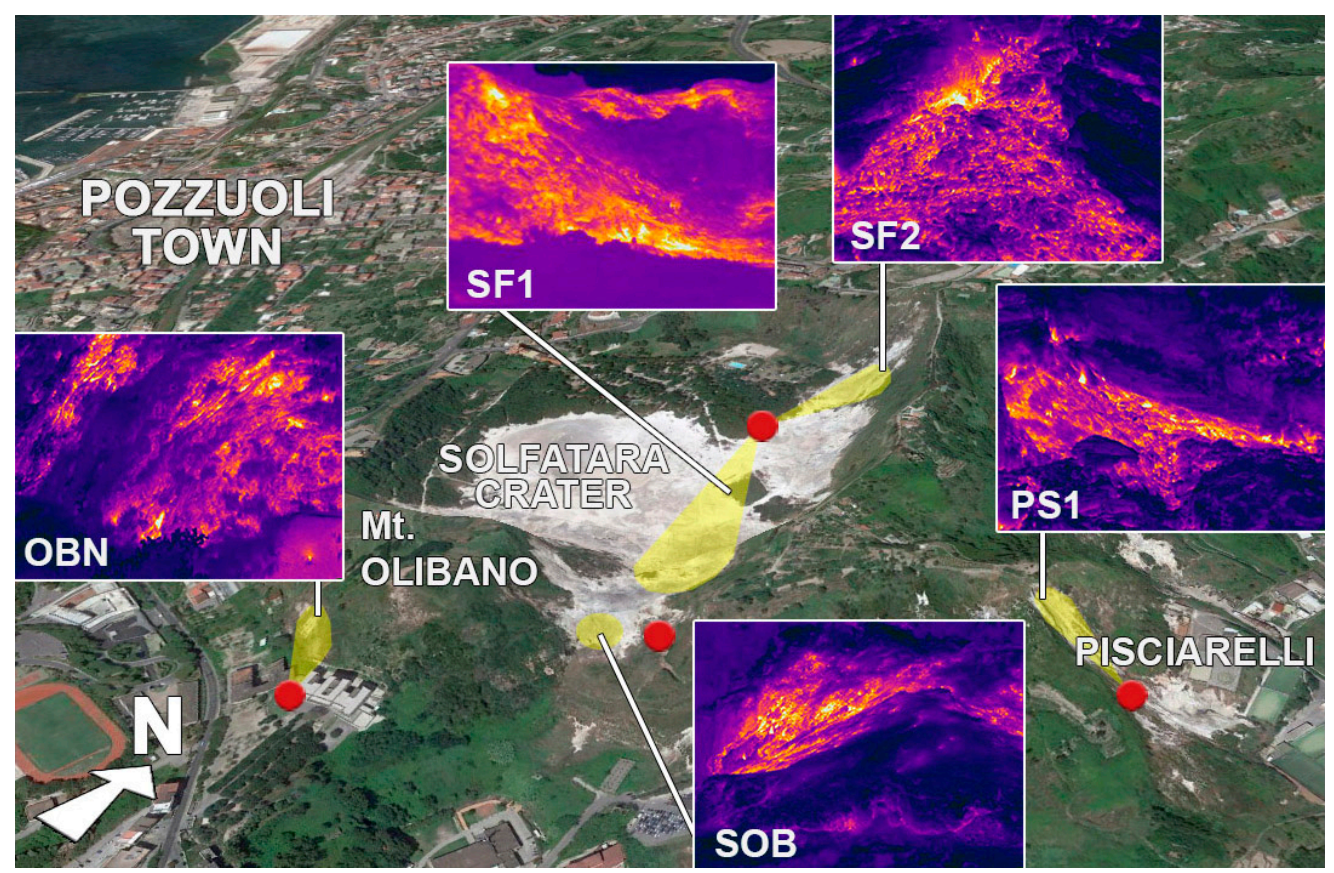

Figure 2. Location of the TIRNet permanent stations (red dots) and the investigated regions (yellow areas). The corresponding infrared (IR) images are shown inside white frames. SF1 = Solfatara Station 1; $\mathrm{SF} 2=$ Solfatara Station 2; SOB = Solfatara OB Station; OBN = Olibano Station; PS1 = Pisciarelli Station.

Each station is equipped with FLIR SC645/655 infrared cameras provided in a focal-plane array (FPA) and an uncooled microbolometer detector whose resolution is $640 \times 480$ pixels, with a spectral range of 7.5-14 $\mu \mathrm{m}$, accuracy of $\pm 2{ }^{\circ} \mathrm{C}$ and thermal sensitivity of $<0.03{ }^{\circ} \mathrm{C} @+30^{\circ} \mathrm{C}$ [60].

TIRNet data are acquired at night time in the absence of solar radiation [61] (pp. 94-97). Daily acquisitions and data transmission are managed remotely through technology developed in-house, allowing continuous time series of infrared (IR) frames [4,62]. Three images are acquired per night (00:00, 02:00 and 04:00 UTC).

The main specifications of the TIRNet stations are reported in Table 3. 
Table 3. Main specifications of TIRNet stations. Refer to Figure 2 for station names and locations.

\begin{tabular}{cccccc}
\hline $\begin{array}{c}\text { Remote } \\
\text { Station }\end{array}$ & Camera Model & $\begin{array}{c}\text { Resolution } \\
\text { (Pixel) }\end{array}$ & $\begin{array}{c}\text { Station UTM } \\
\text { Coordinates (m) }\end{array}$ & $\begin{array}{c}\text { Sensor-Target } \\
\text { Average Distance (m) }\end{array}$ & $\begin{array}{c}\text { Average Pixel } \\
\text { Size (cm) }\end{array}$ \\
\hline SF1 & FLIR A655SC & $640 \times 480$ & $\begin{array}{c}\text { X: } 427.460 \\
\text { Y: } 4.520 .154\end{array}$ & 340 & 23.1 \\
\hline SF2 & FLIR A645SC & $640 \times 480$ & $\begin{array}{c}\text { X: } 427.460 \\
\text { Y: } 4.520 .154\end{array}$ & 114 & 4.6 \\
\hline PS1 & FLIR A645SC & $640 \times 480$ & $\begin{array}{c}\text { X: } 428.081 \\
\text { Y: } 4.520 .117\end{array}$ & 140 & $2.6 \div 5.4$ \\
\hline OBN & FLIR A645SC & $640 \times 480$ & $\begin{array}{c}\text { X: } 427.695 \\
\text { Y: } 4.519 .530\end{array}$ \\
\hline SOB & FLIR A655SC & $640 \times 480$ & $\begin{array}{c}\text { X: } 427.810 \\
\text { Y: } 4.519 .878\end{array}$ & 65 & $5.5 \div 6.7$ \\
\hline
\end{tabular}

\section{Methods and Statistical Analysis}

The procedure proposed in this work is aimed at detecting spatial thermal anomalies in TIR Satellite Frames (TSF) and it is accomplished by performing three main steps: (1) a pre-processing step; (2) a de-seasoning step; and (3) evaluation of thermal anomalies inside the satellite frames.

The first step consists of the geometric correction of TIR Ground Frames (TGF) and the creation of planimetrically corrected images. This step also performs a comparison between TGF and TSF temperature data which provides preliminary information necessary to evaluate the feasibility of the whole procedure. The second step concerns the removal of seasonality from both TGF and TSF. In the third step, the satellite de-seasoned frames are used to detect thermal spatial anomalies.

\subsection{Pre-Processing}

As preliminary step, the surface temperature time-series trends of both TGF and TSF need to be compared. The aim of this comparison is to assess whether the two different time-series have similar behavior so that the processing methodology is applicable. In order to extract the surface temperature time-series, an orthorectification of TGF is necessary. This removes the image geometric distortions by using ArcGIS@ tools $[63,64]$ as required when the images to compare are acquired with a different field of view.

The process of orthorectification of the TGF into the UTM WGS84 coordinate system [65] was performed by using a set of Ground Control Points (GCP) identified both on the TGF and on a Digital Surface Model (DSM) [66] of the studied area. A viewshed analysis was performed for each station by taking into account the field of view (FoV) of thermal cameras, the line of sight and the DSM [64]. In this way, the areas of visibility to use in the further analysis were identified (Figure 3). In particular, the SF1 frame was subdivided into three subsets characterized by different distances between the sensor and the target (Figure 4a).

In order to compare the spatial thermal anomalies of both TGF and TSF, common areas were identified using polygons which were constructed on the basis of a regularly spaced, $30 \times 30 \mathrm{~m}$ large grid. These polygons defined the analysis areas which are shown in Figure $4 \mathrm{~b}$.

In Figure 5, the limits of the analysis areas are overlapped with ASTER and Landsat 8 TIR frames.

Time-series of temperature values inside the analysis areas were created by using the zonal statistical function (ArcGIS $@$ algorithm [64]) which calculates the mean, minimum and maximum temperature values of the analysis areas belonging to all TGF and TSF. The plots in Figure 6 show the comparison between mean temperature values of analysis areas in the TGF and mean temperature values of the same areas in the TSF.

Figure 6 provides evidence that temperature values extracted from TIR frames acquired at different scales were comparable and also that the seasonal component strongly affected the temperature 
trends. This evidence allowed the procedure to continue and removal of the seasonal component to be performed.

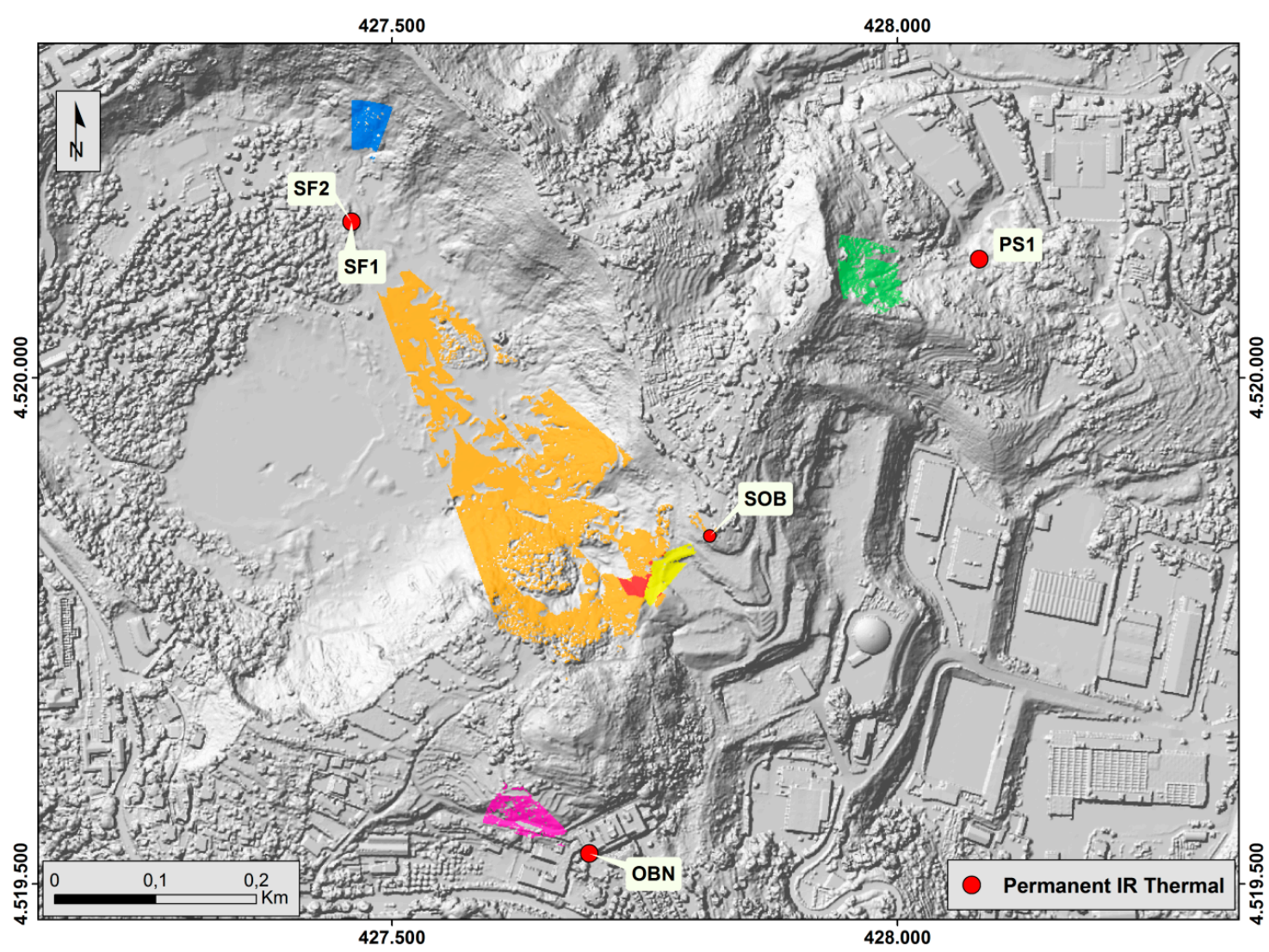

Figure 3. Location and visibility analysis of TIRNet stations in the Campi Flegrei area over the Digital Surface Model (DSM). Lidar data for the DSM were downloaded from the official website Città Metropolitana di Napoli [66] and then processed.

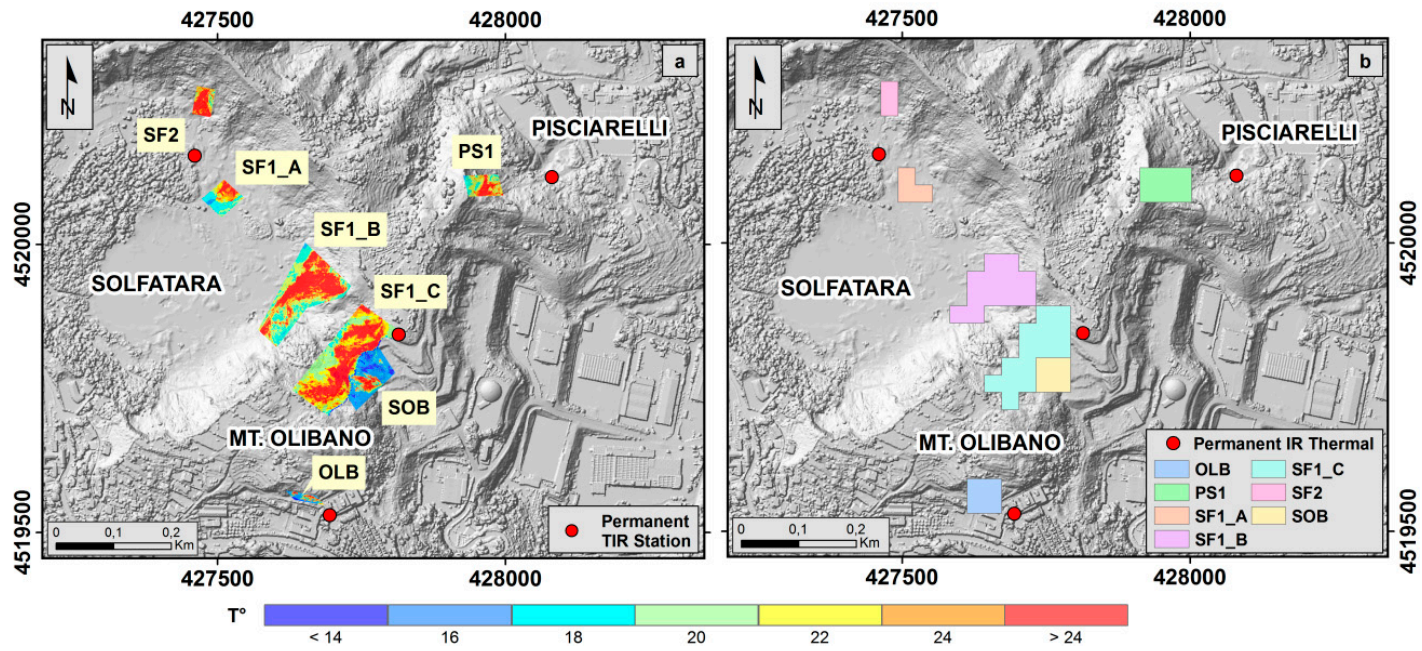

Figure 4. (a) Draped and georeferenced TIR ground frames (TGF) of SF1, SF2, OBN, PS1 and SOB stations. The image of the SF1 Station is split into three coherent parts with different focal geometry (SF1_A/B/C); (b) polygons obtained by grouping cells containing data from TIRNet stations. SF1_A/B/C= Solfatara Station 1; SF2 = Solfatara Station 2; SOB = Solfatara OB Station; OBN = Olibano Station; PS1 = Pisciarelli Station. TIR images were acquired at night time (00:00-04:00). 


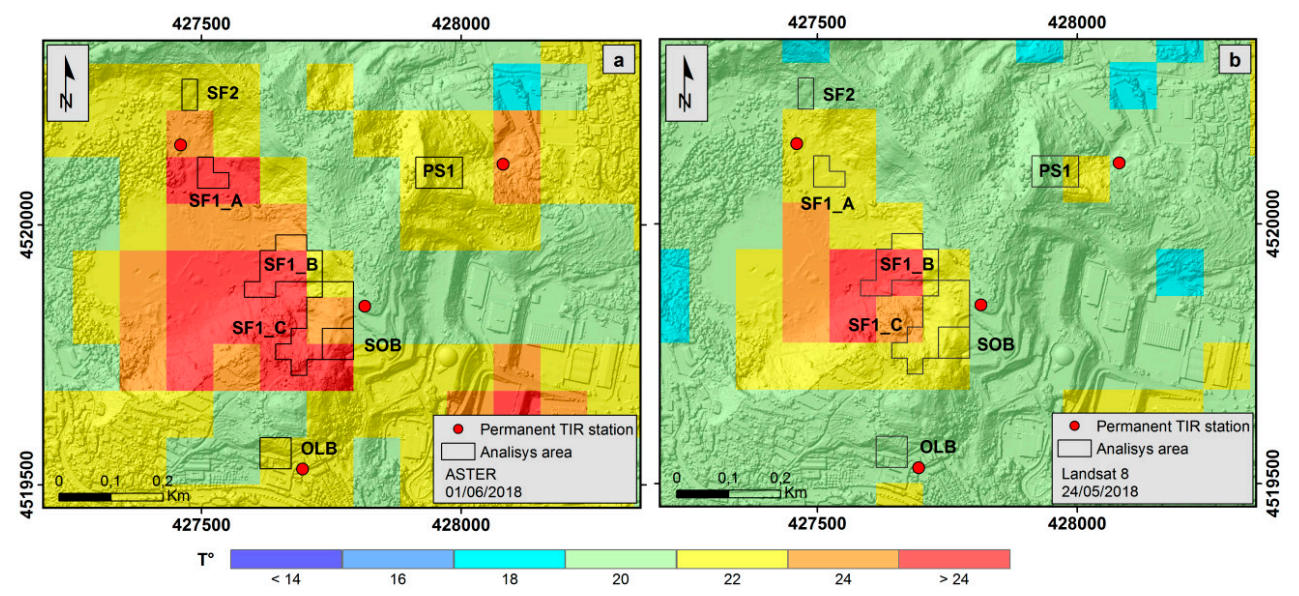

Figure 5. Polygons defining common areas shown in Figure 4 b overlapping ASTER (a) and L8 (b) thermal data of 1 June 2018 and 24 May 2018, respectively.
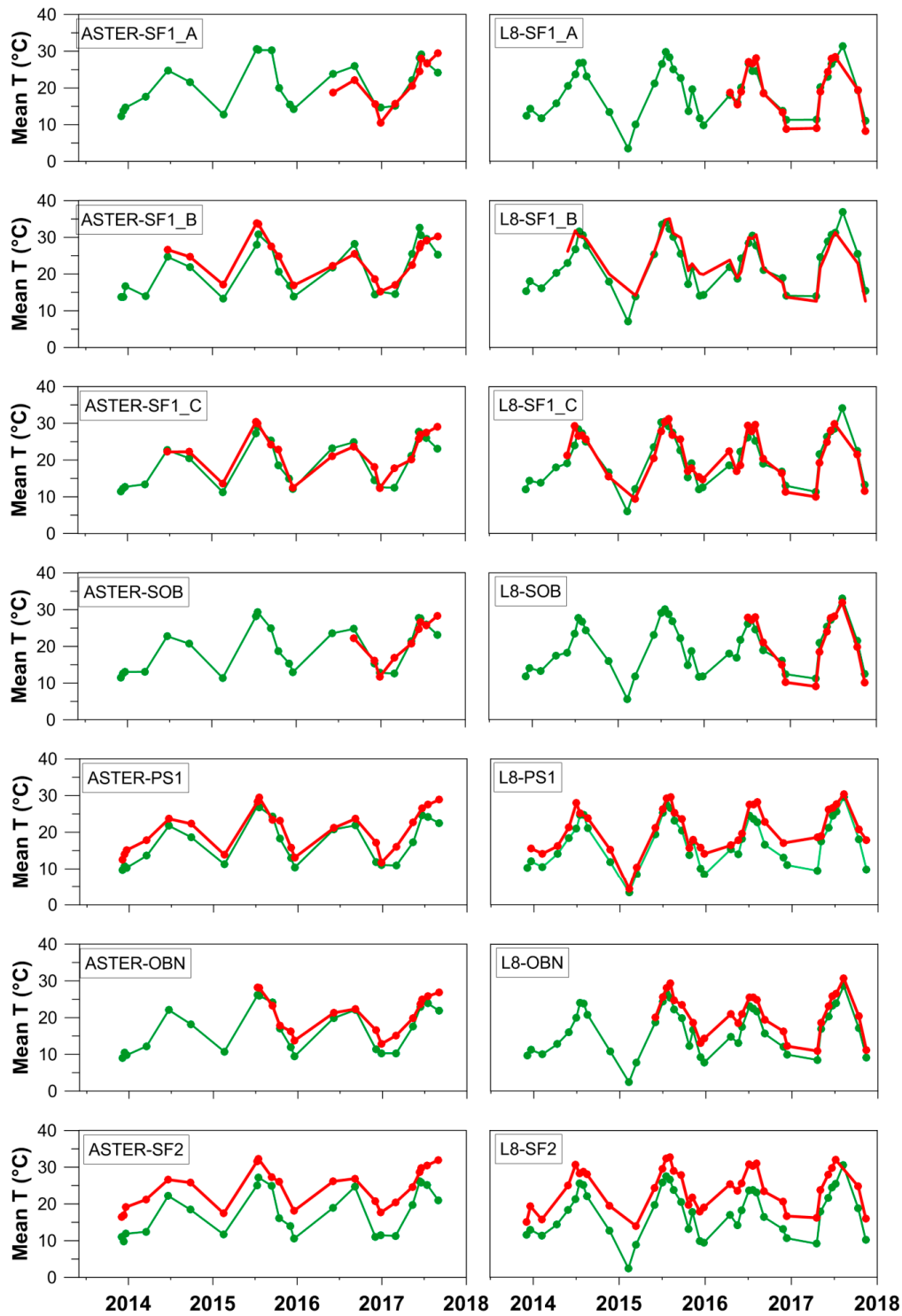

Figure 6. Comparison among temperature time series extracted from satellite and TIRNet analysis areas. Green line = mean temperature of satellite data; red line $=$ mean temperature of TIRNet data. 


\subsection{Seasonal Component Removal}

In order to remove the seasonal component of temperature time-series from TSF it is necessary to evaluate seasonality by applying the Seasonal and Trend decomposition using Loess (STL) method [67,68] to TGF daily continuous temperature time-series. The STL function is based on a locally weighted regression smoother (LOESS) algorithm [67] available in R [69] statistical language and requires almost two years of continuous data. Recent studies have applied STL to detect normalized difference vegetation index (NDVI) changes [70] and to identify anomalous regions within satellite image time series [71].

The STL decomposition method splits temperature data into three main components: seasonality, trend and remainder. Figure 7 shows plots of seasonality time-series obtained from temperature time-series of the PS1, SF2, SF1 and OBN TIRNet stations. Since the seasonality value is almost the same in all temperatures time-series of TIRNet stations, PS1 seasonality was chosen to remove the seasonal effect from all the satellite data frames. The choice of PS1 seasonality was due to the time length of the temperature time-series of this station.

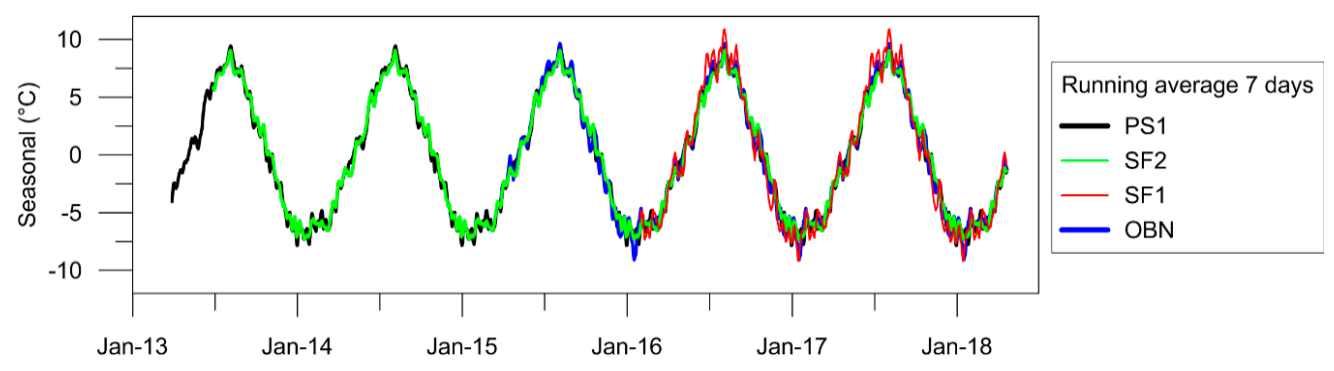

Figure 7. Plots of seasonality values extracted from temperature time-series of PS1, SF2, SF1 and OBN TIRNet ground stations.

This seasonal correction allowed us to highlight in the TSF, the variations of surface temperatures mainly due to the endogenous effects.

\subsection{Evaluation of Thermal Anomalies Inside Satellite Frames}

The seasonal correction of satellite frames produced spatial data which can be used to identify thermally anomalous regions inside the TSF. If sea water is part of the satellite frame, a mask has to be applied to remove the contribution of the water to the temperature distributions.

In order to evaluate the existence of thermally anomalous areas outside the sectors monitored by the TIR ground stations, only land surface Median Temperature values greater than a Threshold Value (MTTV) are selected. The threshold values of $+1 \sigma,+1.5 \sigma$ and $+2 \sigma$ were chosen by evaluating the Gaussian distribution of temperatures belonging to all the pixels of each frame.

The MTTV were used to create maps showing only pixels characterized by the higher temperatures in the observed period. In these maps the urbanized areas were masked to exclude infrared information related to anthropic activity.

\section{Results}

The methodology presented in Section 4 was applied to the Campi Flegrei area (Italy) by processing the datasets described in Section 3. The results are shown in the following sections.

\subsection{Removal of Seasonality to Temperature Time-Series}

The plots of the de-seasoned temperature time-series of the anomalous areas (Figure 4) of the TGF (cyan line) and TSF (black line) are shown in Figure 8. TGF were acquired by TIRNet ground stations, and TSF were acquired by ASTER and L8 satellites. These plots enable comparisons of the variations in time of temperatures inside the anomalous areas common to both satellite and ground data. 

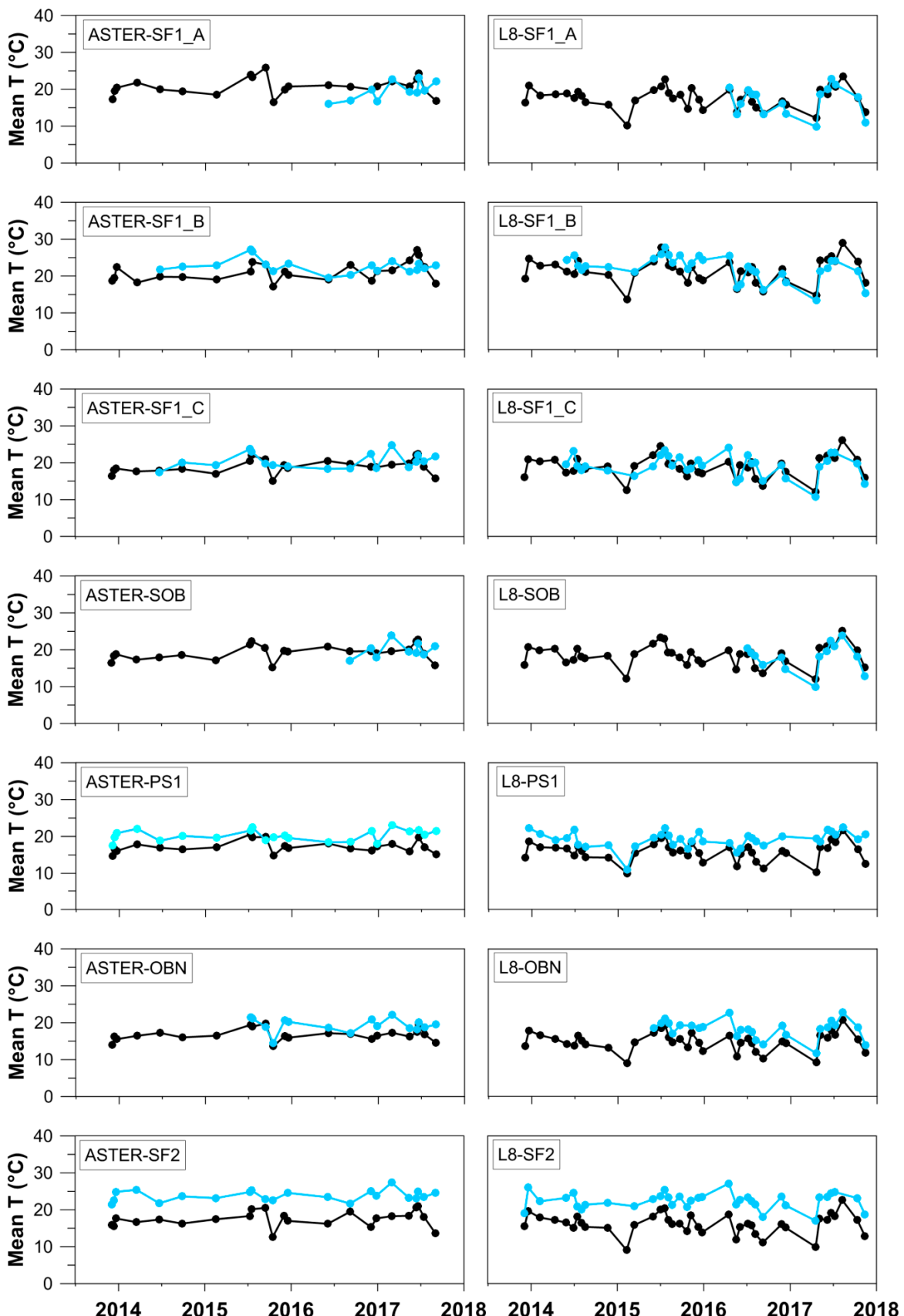

Figure 8. Comparisons among time-series from ASTER/L8 and TIRNet data with seasonality removed, detected at the PS1 ground station. Black line = mean temperatures of anomalous areas inside the TSF. Cyan line $=$ mean temperatures of anomalous areas inside the TGF. Labels of the plots refer to the names of the anomalous areas as shown in Figures 4 and 5.

\subsection{Maps of De-seasoned Temperatures of Satellite Frames}

In Figure 9, the maps of land surface median de-seasoned temperatures of TSF are shown. Sea water was not removed, and urban areas are also present.

In Figure 10, the maps of MTTV are shown. These maps were created after masking the sea water and using median temperatures values higher than three different threshold values (see Section 4.3). The threshold values used are reported in Table 4 . These values were evaluated according to the Gaussian distribution of temperature values of each TSF. The pixels falling inside urbanized areas are not shown in these maps. 


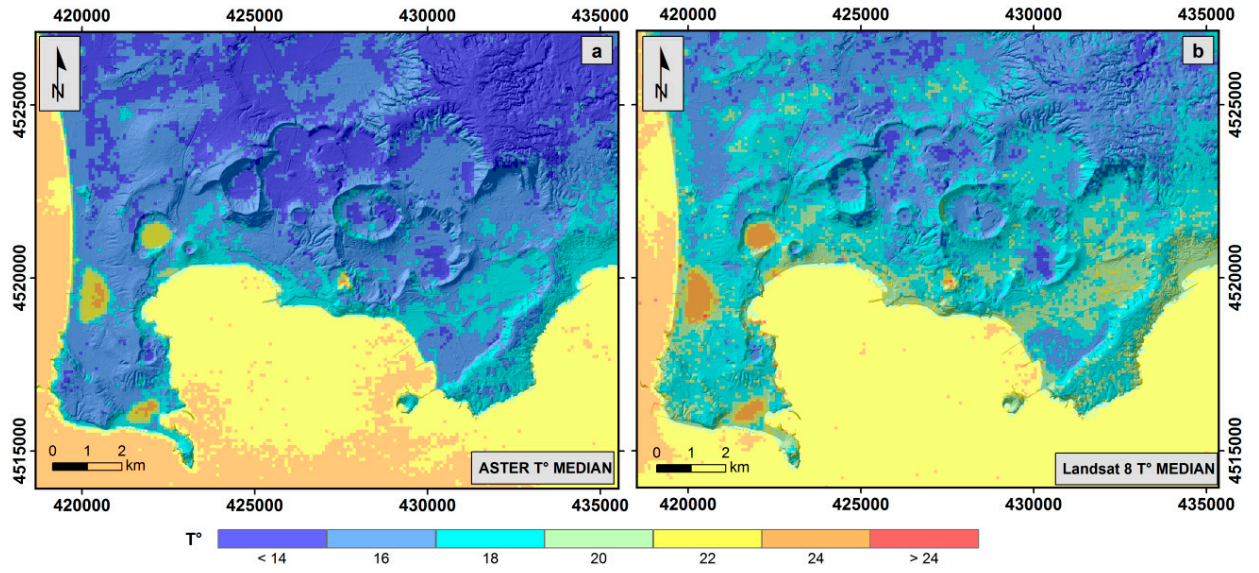

Figure 9. Maps of land surface median temperature values of ASTER (a) and L8 (b) de-seasoned time-series.

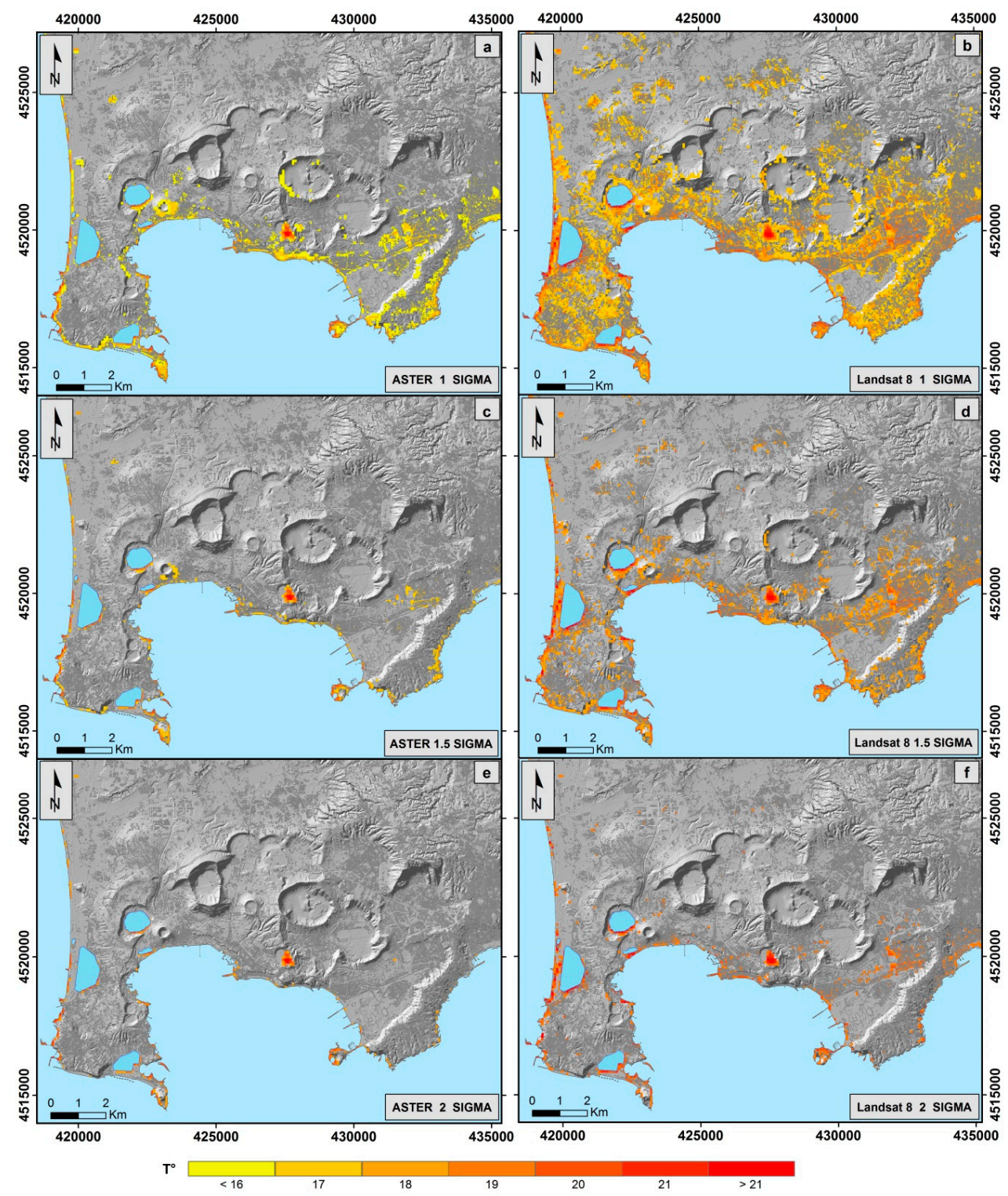

Figure 10. Maps of Median Temperature values greater than a Threshold Value (MTTV) of TSF with temperature thresholds of: $+1 \sigma(\mathbf{a}, \mathbf{b}) ;+1.5 \sigma(\mathbf{c}, \mathbf{d}) ; 2 \sigma(\mathbf{e}, \mathbf{f})$. 
Table 4. Threshold values used to extract temperatures representative of thermal anomalies in TIR Satellite Frames (TSF) (see Section 4.3).

\begin{tabular}{ccc}
\hline Thresholds & ASTER & L8 \\
\hline$+1 \sigma$ & $16.36^{\circ} \mathrm{C}$ & $17.01^{\circ} \mathrm{C}$ \\
$+1.5 \sigma$ & $17.19^{\circ} \mathrm{C}$ & $18.02^{\circ} \mathrm{C}$ \\
$+2 \sigma$ & $18.03^{\circ} \mathrm{C}$ & $19.04^{\circ} \mathrm{C}$ \\
\hline
\end{tabular}

The MTTV maps show the presence of areas characterized by high temperatures which were stable during the period of data acquisition.

\section{Discussion}

A key requirement to validate the proposed procedure (see Section 4) is the comparison between the temperature trends extracted by TGF and by TSF. The effectiveness of this comparison depends on the accuracy of the pre-processing phase consisting of geometric correction and co-registration of different datasets (see Section 4.1). If this phase is not able to provide good quality results, due to the intrinsic properties of TIR data, the subsequent steps of the procedure can not be performed. The plots in Figure 6, produced at the end of the pre-processing phase, provided evidence that TGF and TSF temperature values differed up to a maximum of only two degrees, and showed common trend behaviour. This result allowed us to continue with the next steps of the procedure Since these temperature trends were clearly affected by significant seasonal influence, the second step of procedure was applied to remove the seasonal component of the data. The efficacy of this step is clearly shown in Figure 8, where the TIRNet and satellite mean temperature time-series are not affected by the typical oscillating behaviour due to seasonality. In the same figure, it is also evident that after the seasonal correction, the behaviour of temperature time-series of TIRNet and satellite data are very similar.

Regarding the temperature time-series in Figure 8, some observations can be made: (1) ASTER mean temperatures were characterized by a more stable trend then L8 mean temperatures, probably due to the lower sampling rate of ASTER data; (2) in the first months of 2015, L8 time-series showed a negative peak, likely due to a very cold end of winter; (3) both ASTER and L8 data showed a negative peak corresponding to October 2015.

The evidence from the third observation could suggest a correlation between the negative peak of temperatures and the occurrence of moderate magnitude earthquake swarms in the Campi Flegrei area on 7 October of the same year. The higher magnitude event $(\mathrm{Md}=2.5)$ was also the larger one that occurred in the observation period.

The maps of de-seasoned median temperatures of satellite frames (Figure 9) provide evidence that higher temperature values are representative both of water bodies and small inland areas. In order to highlight thermal anomalies due to volcanic activity, it is necessary to mask water bodies and every thermal source of anthropic origin. This task has been achieved in Figure 10 by masking water bodies and representing only pixels whose temperature is higher than the different threshold values reported in Table 4.

The MTTV map of Figure 10a, obtained by using the $1 \sigma$ threshold value of the ASTER frames, show clusters of pixels characterized by high temperatures along the coastal line, volcanic edifices and urbanized areas. In Figure 10c (threshold value $=1.5 \sigma$ ) high temperature pixels are located mainly over the volcanic edifices of Solfatara and Monte Nuovo (see Figure 1) and subordinately along coastal lines. Also, a few pixels are located near highly urbanized areas. In Figure 10e, only the Solfatara volcanic area and a few coastal places are highlighted by high temperature pixels. Landsat 8 maps of Figure $10 \mathrm{~b}, \mathrm{~d}, \mathrm{f}$ show similar behaviour as the ASTER maps, although the number of high temperature pixels is considerably greater, likely due to the different IR sensor sensibility.

These observations indicate that in the Campi Flegrei area the Solfatara volcanic centre is characterized by higher median temperatures of TSF. Furthermore, the Monte Nuovo volcanic area 
shows high median temperature pixels which are evidenced when using low threshold values ( 1 and $1.5 \sigma)$ only.

This evidence is consistent with the intense volcanic degassing activity, which is strongly clustered in the Solfatara area, and subordinately at the Monte Nuovo volcanic centre. Finally, in the observed period, no unknown thermally anomalous areas related to volcanic activity were highlighted in other sectors of Campi Flegrei.

\section{Conclusions}

A common problem occurring when analyzing spatio-temporal variation of land surface temperatures by satellite observations, concerns the methodology used to remove seasonal influence from the data. The present study proposed a methodology aimed at cleaning up the thermal infrared (TIR) satellite images of the seasonal effect in order to identify surface spatial thermal anomalies. This methodology consists of three main steps.

In the first step, a geometric correction of TGF is performed and planimetrically corrected images are produced in order to define thermal anomaly areas common to ground and satellite imagery. In this way, TGF and TSF data can be compared as this is necessary to evaluate the achievability of the whole procedure.

In the second step, the removal of the seasonal component of TSF is carried out. The seasonal component is obtained by applying the STL decomposition method to the daily continuous TGF temperature time-series and then subtracting it from TSF temperature time-series.

In the final step, land surface median temperature values are evaluated to create maps to identify areas affected by thermal anomalies. In these maps, urbanized areas and sea water are masked in order to show only land pixels not influenced by anthropic activity and characterized by the higher temperatures of the observed period. To remove pixels related to background temperatures and highlight only the pixels associated to thermal anomalies, the median temperature values higher than three different threshold values are used to produce different maps. These threshold values $(+1 \sigma$, $+1.5 \sigma$ and $+2 \sigma)$ are estimated on the basis of the Gaussian distribution of all temperatures of each TSF.

The proposed methodology was applied to the Campi Flegrei volcanic area (Italy) by using TGF acquired by the TIRNet volcanic surveillance network (INGV, Osservatorio Vesuviano) and ASTER and Landsat 8 TGF ranging from July 2013 to November 2017.

The preliminary comparison (step 1) showed good agreement among the temperature time-series of TGF and TSF, allowing the procedure to continue.

The removal of the seasonal effect (step 2) produced plots of de-seasoned temperatures not affected by the typical oscillating behaviour due to seasonality. The occurrence in October 2015 of both a negative peak of satellite/ground temperatures and of moderate magnitude earthquake swarms in the Campi Flegrei area, was observed. This is an interesting starting point to begin a multidisciplinary discussion about surface thermal behaviour during a seismic crisis.

As product of the third step, different maps of land surface median temperature values were produced by applying different temperature threshold values. The maps show that the higher the threshold value is, the more thermal anomalies mainly related to anthropic or sea water influence are excluded. At the same time, the thermal anomalies due to the degassing activity of the Solfatara and Monte Nuovo volcanic edifices are highlighted.

As a final observation, no evidence of anomalous areas connected to volcanic activity were detected in the Campi Flegrei area covered by TSF.

The feasibility of the proposed methodology depends mainly on: (1) the availability of continuous TGF time-series which has to be almost two-years long; (2) the proper correction of TGF acquisition geometry; (3) the absence of intense urbanization; and (4) the presence of significant high temperature thermal anomalies in the studied area. 
In conclusion, the methodology proposed in this work can provide a useful tool to improve the contribution of satellite data to volcanic/environmental surveillance aimed at analyzing the possible spatial variations of land surface temperatures.

Author Contributions: T.C. and E.B.S. developed the methodology, processed TIRNet data and compared them with satellite data, and wrote the manuscript with contributions from all authors; T.C. and F.S. applied the STL algorithm on time series for de-seasoning data; E.B.S. realized DSM and DTM from Lidar data; M.S. and M.M. processed satellite data to retrieve the surface temperature; M.F.B. conceived the idea for this manuscript; F.S. and G.V. designed and operated TIRNet; All authors contributed to the ideas, writing, and discussion.

Funding: This research received no external funding.

Acknowledgments: We would like to thank POR (Programma Operativo Regionale) Campania FESR (Fondo Europeo per lo Sviluppo Regionale) 2007-2013-Progetto SISTEMA (Sistema Integrato di Sorveglianza del TErritorio con Metodologie Aerospaziali). The ASTER L1T and ASTER05 data were retrieved from the online Data tool, courtesy of the NASA EOSDIS Land Processes Distributed Active Archive Center (LP DAAC), USGS/Earth Resources Observation and Science (EROS) Center, Sioux Falls, South Dakota, [https://earthexplorer.usgs.gov/]. Landsat 8 L1T processing, archiving, and distribution are performed by the USGS.

Conflicts of Interest: The authors declare no conflicts of interest.

\section{References}

1. La Rocca, M.; Galluzzo, D. Seismic monitoring of Campi Flegrei and Vesuvius by stand-alone instruments. Ann. Geophys. 2015, 58, S0544. [CrossRef]

2. Sansivero, F.; Vilardo, G.; De Martino, P.; Augusti, V.; Chiodini, G. Campi Flegrei volcanic surveillance by thermal IR continuous monitoring. In Proceedings of the 11th International Conference on Quantitative InfraRed Thermography, Naples, Italy, 11-14 June 2012.

3. De Martino, P.; Tammaro, U.; Obrizzo, F. GPS time series at Campi Flegrei caldera (2000-2013). Ann. Geophys. 2014, 57, 0213.

4. Vilardo, G.; Sansivero, F.; Chiodini, G. Long-term TIR imagery processing for spatiotemporal monitoring of surface thermal features in volcanic environment: A case study in the Campi Flegrei (Southern Italy). J. Geophys. Res. Solid Earth 2015, 120, 812-826. [CrossRef]

5. Calvari, S.; Lodato, L.; Spampinato, L. Monitoring active volcanoes using a handheld thermal camera. Proc. SPIE 2004, 5405, 199-210.

6. Chiodini, G.; Vilardo, G.; Augusti, V.; Granieri, D.; Caliro, S.; Minopoli, C.; Terranova, C. Thermal monitoring of hydrothermal activity by permanent infrared automatic stations: Results obtained at Solfatara di Pozzuoli, Campi Flegrei (Italy). J. Geophys. Res. Solid Earth 2007, 112. [CrossRef]

7. Walter, T.R.; Legrand, D.; Granados, H.D.; Reyes, G.; Arámbula, R. Volcanic eruption monitoring by thermal image correlation: Pixel offsets show episodic dome growth of the Colima volcano. J. Geophys. Res. Solid Earth 2013, 118, 1408-1419. [CrossRef]

8. Patrick, M.R.; Kauahikaua, J.; Orr, T.; Davies, A.; Ramsey, M. Operational thermal remote sensing and lava flow monitoring at the Hawaiian Volcano Observatory. Geol. Soc. Lond. Spec. Publ. 2016, 426, 489-503. [CrossRef]

9. Mia, M.B.; Fujimitsu, Y.; Nishijima, J. Thermal Activity Monitoring of an Active Volcano Using Landsat 8/OLI-TIRS Sensor Images: A Case Study at the Aso Volcanic Area in Southwest Japan. Geosciences 2017, 7, 118.

10. Blackett, M. An overview of infrared remote sensing of volcanic activity. J. Imaging 2017, 3, 13. [CrossRef]

11. Pieri, D.; Abrams, M. ASTER watches the world's volcanoes: A new paradigm for volcanological observations from orbit. J. Volcanol. Geotherm. Res. 2004, 135, 13-28. [CrossRef]

12. Carter, A.; Ramsey, M. Long-term volcanic activity at Shiveluch volcano: Nine years of ASTER Spaceborne thermal infrared observations. Remote Sens. 2010, 2, 2571-2583. [CrossRef]

13. Ramsey, M.S. What more have we learned from thermal infrared remote sensing of active volcanoes other than they are hot? In Proceedings of the American Geophysical Union, Fall Meeting 2009, San Francisco, CA, USA, 14-18 December 2009.

14. Ramsey, M.S.; Flynn, L.P. Strategies, insights, and the recent advances in volcanic monitoring and mapping with data from NASA's Earth Observing System. J. Volcanol. Geotherm. Res. 2004, 135, 1-11. [CrossRef] 
15. Ramsey, M.S.; Wessels, R.L.; Anderson, S.A. Surface textures and dynamics of the 2005 lava dome at Shiveluch Volcano, Kamchatka. Geol. Soc. Am. Bull. 2012, 124, 678-689. [CrossRef]

16. Sobrino, J.A.; Del Frate, F.; Drusch, M.; Jiménez-Muñoz, J.C.; Manunta, P.; Regan, A. Review of thermal infrared applications and requirements for future high-resolution sensors. IEEE Trans. Geosci. Remote Sens. 2016, 54, 2963-2972. [CrossRef]

17. Schmetz, J.; Pili, P.; Tjemkes, S.; Just, D.; Kerkmann, J.; Rota, S.; Ratier, A. An introduction to Meteosat second generation (MSG). Bull. Am. Meteorol. Soc. 2002, 83, 977-992. [CrossRef]

18. Sun, D.; Pinker, R.T. Estimation of land surface temperature from a Geostationary Operational Environmental Satellite (GOES-8). J. Geophys. Res. Atmos. 2003, 108. [CrossRef]

19. Wan, Z.; Snyder, W. MODIS Land-Surface Temperature Algorithm Theoretical Basis Document (LST ATBD), Version 3.2; Institute for Computational Earth System Science, University of California: Santa Barbara, CA, USA, 1996.

20. Li, Z.-L.; Becker, F. Feasibility of land surface temperature and emissivity determination from AVHRR data. Remote Sens. Environ. 1993, 85, 67-85. [CrossRef]

21. Donlon, C.; Berruti, B.; Buongiorno, A.; Ferreira, M.H.; Féménias, P.; Frerick, J.; Goryl, P.; Klein, U.; Laur, H.; Mavrocordatos, C.; et al. The Global Monitoring for Environment and Security (GMES) Sentinel-3 mission. Remote Sens. Environ. 2012, 120,37-57. [CrossRef]

22. Buongiorno, M.F.; Pieri, D.; Silvestri, M. Thermal analysis of volcanoes based on 10 years of ASTER data on Mt. Etna. In Thermal Infrared Remote Sensing; Sensors, Methods, Applications; Springer: Dordrecht, The Netherlands, 2013; pp. 409-428.

23. Coppola, D.; Laiolo, M.; Cigolini, C.; Delle Donne, D.; Ripepe, M. Enhanced volcanic hot-spot detection using MODIS IR data: results from the MIROVA system. Geol. Soc. Lond. Spec. Publ. 2016, 426, 181-205. [CrossRef]

24. Harris, A.; Butterworth, A.; Carlton, R.; Downey, I.; Miller, P.; Navarro, P.; Rothery, D. Low-cost volcano surveillance from space: Case studies from Etna, Krafla, Cerro Negro, Fogo, Lascar and Erebus. Bull. Volcanol. 1997, 59, 49-64. [CrossRef]

25. Lombardo, V.; Harris, A.J.L.; Calvari, S.; Buongiorno, M.F. Spatial variations in lava flow field thermal structure and effusion rate derived from very high spatial resolution hyperspectral (MIVIS) data. J. Geophys. Res. Solid Earth 2009, 114. [CrossRef]

26. Harris, A.J.; Rose, W.I.; Flynn, L.P. Temporal trends in lava dome extrusion at Santiaguito 1922-2000. Bull. Volcanol. 2003, 65, 77-89. [CrossRef]

27. Van Manen, S.M.; Dehn, J.; Blake, S. Satellite thermal observations of the Bezymianny lava dome 1993-2008: Precursory activity, large explosions, and dome growth. J. Geophys. Res. Solid Earth 2010, 115. [CrossRef]

28. Higgins, J.; Harris, A. VAST: A program to locate and analyse volcanic thermal anomalies automatically from remotely sensed data. Comput. Geosci. 1997, 23, 627-645. [CrossRef]

29. Silvestri, M.; Cardellini, C.; Chiodini, G.; Buongiorno, M.F. Satellite-derived surface temperature and in situ measurement at Solfatara of Pozzuoli (Naples, Italy). Geochem. Geophys. Geosyst. 2016, 17, 2095-2109. [CrossRef]

30. Harris, A.J.L.; Wright, R.; Flynn, L.P. Remote Monitoring of Mount Erebus Volcano, Antarctica, Using Polar Orbiters: Progress and Prospects. Int. J. Remote Sens. 1999, 20, 3051-3071. [CrossRef]

31. Hernández, P.A.; Calvari, S.; Ramos, A.; Pérez, N.M.; Márquez, A.; Quevedo, R.; Barrancos, J.; Padrón, E.; Padilla, G.D.; López, D.; et al. Magma emission rates from shallow submarine eruptions using airborne thermal imaging. Remote Sens. Environ. 2014, 154, 219-225. [CrossRef]

32. Oppenheimer, C.; Yirgu, G. Thermal imaging of an active lava lake: Erta 'Ale volcano, Ethiopia. Int. J. Remote Sens. 2002, 23, 4777-4782. [CrossRef]

33. Laiolo, M.; Coppola, D.; Barahona, F.; Benítez, J.E.; Cigolini, C.; Escobar, D.; Funes, R.; Gutierrez, E.; Henriquez, B.; Hernandez, A.; et al. Evidences of volcanic unrest on high-temperature fumaroles by satellite thermal monitoring: The case of Santa Ana volcano, El Salvador. J. Volcanol. Geotherm. Res. 2017, 340, 170-179. [CrossRef]

34. Aufaristama, M.; Hoskuldsson, A.; Jonsdottir, I.; Ulfarsson, M.O.; Thordarson, T. New insights for detecting and deriving thermal properties of lava flow using infrared satellite during 2014-2015 effusive eruption at Holuhraun, Iceland. Remote Sens. 2018, 10, 151. [CrossRef]

35. Spampinato, L.; Oppenheimer, C.; Cannata, A.; Montalto, P.; Salerno, G.G.; Calvari, S. On the time-scale of thermal cycles associated with open-vent degassing. Bull. Volcanol. 2012, 74, 1281-1292. [CrossRef] 
36. Gresse, M.; Vandemeulebrouck, J.; Byrdina, S.; Chiodini, G.; Revil, A.; Johnson, T.C.; Ricci, T.; Vilardo, G.; Mangiacapra, A.; Lebourg, T.; et al. Three-Dimensional Electrical Resistivity Tomography of the Solfatara Crater (Italy): Implication for the Multiphase Flow Structure of the Shallow Hydrothermal System. J. Geophys. Res. Solid Earth 2017, 122, 8749-8768. [CrossRef]

37. Orsi, G.; De Vita, S.; di Vito, M. The restless, resurgent Campi Flegrei nested caldera (Italy): constraints on its evolution and configuration. J. Volcanol. Geotherm. Res. 1996, 74, 179-214. [CrossRef]

38. Orsi, G.; Civetta, L.; Del Gaudio, C.; de Vita, S.; Di Vito, M.A.; Isaia, R.; Petrazzuoli, S.M.; Ricciardi, G.P.; Ricco, C. Short-term ground deformations and seismicity in the resurgent Campi Flegrei caldera (Italy): An example of active block-resurgence in a densely populated area. J. Volcanol. Geotherm. Res. 1999, 91, 415-451. [CrossRef]

39. Di Vito, M.; Isaia, R.; Orsi, G.; Southon, J.; de Vita, S.; D’Antonio, M.; Pappalardo, L.; Piochi, M. Volcanism and deformation since 12,000 years at the Campi Flegrei caldera (Italy). J. Volcanol. Geotherm. Res. 1999, 91, 221-246. [CrossRef]

40. Deino, A.L.; Orsi, G.; de Vita, S.; Piochi, M. The age of the Neapolitan Yellow Tuff caldera-forming eruption (Campi Flegrei caldera-Italy) assessed by 40Ar/39Ar dating method. J. Volcanol. Geotherm. Res. 2004, 133, 157-170. [CrossRef]

41. Vitale, S.; Isaia, R. Fractures and faults in volcanic rocks (Campi Flegrei, southern Italy): Insight Into Volcano-tectonic processes. Int. J. Earth Sci. 2014, 103, 801-819. [CrossRef]

42. Scarpati, C.; Sparice, D.; Perrotta, A. Comparative proximal features of the main Plinian deposits (Campanian Ignimbrite and Pomici di Base) of Campi Flegrei and Vesuvius. J. Volcanol. Geotherm. Res. 2016, 321, 149-157. [CrossRef]

43. Di Vito, M.A.; Acocella, V.; Aiello, G.; Barra, D.; Battaglia, M.; Carandente, A.; Del Gaudio, C.; de Vita, S.; Ricciardi, G.P.; Ricco, C.; et al. Magma transfer at Campi Flegrei caldera (Italy) before the 1538 AD eruption. Sci. Rep. 2016, 6, 32245. [CrossRef]

44. Del Gaudio, C.; Aquino, I.; Ricciardi, G.P.; Ricco, C.; Scandone, R. Unrest episodes at Campi Flegrei: A reconstruction of vertical ground movements during 1905-2009. J. Volcanol. Geotherm. Res. 2010, 195, 48-56. [CrossRef]

45. Iannaccone, G.; Guardato, S.; Donnarumma, G.P.; De Martino, P.; Dolce, M.; Macedonio, G.; Chierici, F.; Beranzoli, L. Measurement of Seafloor Deformation in the Marine Sector of the Campi Flegrei Caldera (Italy). J. Geophys. Res. Solid Earth 2018, 123, 66-83. [CrossRef]

46. Caliro, S.; Chiodini, G.; Moretti, R.; Avino, R.; Granieri, D.; Russo, M.; Fiebig, J. The origin of the fumaroles of La Solfatara (Campi Flegrei, South Italy). Geochim. Cosmochim. Acta 2007, 71, 3040-3055. [CrossRef]

47. Chiodini, G.; Avino, R.; Caliro, S.; Minopoli, C. Temperature and pressure gas geoindicators at the Solfatara fumaroles (Campi flegrei). Ann. Geophys. 2011, 54, 151-160.

48. Chiodini, G.; Caliro, S.; Cardellini, C.; Granieri, D.; Avino, R.; Baldini, A.; Donnini, M.; Minopoli, C. Long-term variations of the Campi Flegrei, Italy, volcanic system as revealed by the monitoring of hydrothermal activity. J. Geophys. Res. 2010, 115, B03205. [CrossRef]

49. Chiodini, G.; Vandemeulebrouck, J.; Caliro, S.; D'Auria, L.; De Martino, P.; Mangiacapra, A.; Petrillo, Z. Evidence of thermal-driven processes triggering the 2005-2014 unrest at Campi Flegrei caldera. Earth Planet. Sci. Lett. 2015, 414, 58-67. [CrossRef]

50. Landsat Missions Timeline | Landsat Missions. Available online: https://landsat.usgs.gov/landsat-missionstimeline (accessed on 2 October 2018).

51. USGS. Landsat 8 (L8) Data Users Handbook; Version 2.0; EROS: Sioux Falls, SD, USA, 2016.

52. Barsi, J.A.; Barker, J.L.; Schott, J.R. An Atmospheric Correction Parameter Calculator for a single thermal band earth-sensing instrument. In Proceedings of the IGARSS 2003, Toulouse, France, 21-25 July 2003.

53. Silvestri, M.; Rabuffi, F.; Pisciotta, A.; Musacchio, M.; Diliberto, I.S.; Spinetti, C.; Lombardo, V.; Colini, L.; Buongiorno, M.F. Analysis of Thermal Anomalies in Volcanic Areas Using Multiscale and Multitemporal Monitoring: Vulcano Island Test Case. Remote Sens. 2019, 11, 134. [CrossRef]

54. ASTER Mission. Available online: https://asterweb.jpl.nasa.gov/mission.asp (accessed on 2 October 2018).

55. Kahle, A.B.; Palluconi, F.D.; Hook, S.J.; Realmuto, V.J.; Bothwell, G. The advanced spaceborne thermal emission and reflectance radiometer (Aster). Int. J. Imaging Syst. Technol. 1991, 3, 144-156. [CrossRef] 
56. Ramsey, M.; Dehn, J. Spaceborne observations of the 2000 Bezymianny, Kamchatka eruption: the integration of high-resolution ASTER data into near real-time monitoring using AVHRR. J. Volcanol. Geotherm. Res. 2004, 135, 127-146. [CrossRef]

57. Carter, A.J.; Ramsey, M.S.; Belousov, A.B. Detection of a new summit crater on Bezymianny Volcano lava dome: satellite and field-based thermal data. Bull. Volcanol. 2007, 69, 811-815. [CrossRef]

58. Ramsey, M.S. Closing the terrestrial-planetary remote sensing loop: Spectral, spatial and physical proxies. In Proceedings of the American Geophysical Union, Fall Meeting 2002, San Francisco, CA, USA, 6-10 December 2002.

59. Gillespie, A.; Rokugawa, S.; Matsunaga, T.; Cothern, J.S.; Hook, S.; Kahle, A.B. A temperature and emissivity separation algorithm for Advanced Spaceborne Thermal Emission and Reflection Radiometer (ASTER) images. IEEE Trans. Geosci. Remote Sens. 1998, 36, 1113-1126. [CrossRef]

60. FLIR A655sc High-Resolution Science Grade LWIR Camera | FLIR Systems. Available online: https: //www.flir.com/products/a655sc/ (accessed on 25 September 2018).

61. Harris, A. Thermal Remote Sensing of Active Volcanoes: A User's Manual; Cambridge University Press: Cambridge, UK, 2013; ISBN 052185945X.

62. Sansivero, F.; Scarpato, G.; Vilardo, G. The automated infrared thermal imaging system for the continuous long-term monitoring of the surface temperature of the Vesuvius crater. Ann. Geophys. 2013, 56, S0454.

63. Liu, X.; Zhang, Z.; Peterson, J.; Chandra, S. LiDAR-Derived High Quality Ground Control Information and DEM for Image Orthorectification. Geoinform. 2007, 11, 37-53. [CrossRef]

64. ESRI. ArcGIS Desktop: Release 10; Environmental Systems Research Institute, Inc.: Redlands, CA, USA, 2011.

65. Silvestri, M.; Diaz, J.A.; Marotta, E.; Dalla Via, G.; Bellucci Sessa, E.; Caputo, T.; Buongiorno, M.F.; Sansivero, F.; Musacchio, M.; Belviso, P.; et al. The 2016 Field Campaign of La Solfatara Volcano: Monitoring Methods and Instruments for Volcanic Surveillance; Technical Report; INGV: Roma, Italy, 2017.

66. Città Metropolitana di Napoli-Telerilevamento mediante Lidar. Available online: http://sit. cittametropolitana.na.it/lidar.html (accessed on 19 October 2018).

67. Cleveland, R.B.; Cleveland, W.S.; McRae, J.E.; Terpenning, I.J. STL: A seasonal-trend decomposition procedure based on loess. J. Off. Stat. 1990, 6, 3-73.

68. Sansivero, F.; Vilardo, G. Processing Thermal Infrared Imagery Time-Series from Volcano Permanent Ground-Based Monitoring Network. Latest Methodological Improvements to Characterize Surface Temperatures Behavior of Thermal Anomaly Areas. Remote Sens. 2019, 11, 553. [CrossRef]

69. R Development Core Team. R: A Language and Environment for Statistical Computing; R Foundation for Statistical Computing: Vienna, Austria, 2014.

70. Verbesselt, J.; Hyndman, R.; Newnham, G.; Culvenor, D. Detecting trend and seasonal changes in satellite image time series. Remote Sens. Environ. 2010, 114, 106-115. [CrossRef]

71. Zhou, Z.G.; Tang, P.; Zhou, M. Detecting anomaly regions in satellite image time series based on seasonal autocorrelation analysis. ISPRS Ann. Photogramm. Remote Sens. Spat. Inf. Sci 2016, 303-310. [CrossRef]

(C) 2019 by the authors. Licensee MDPI, Basel, Switzerland. This article is an open access article distributed under the terms and conditions of the Creative Commons Attribution (CC BY) license (http://creativecommons.org/licenses/by/4.0/). 